\title{
Rubroshiraia gen. nov., a second hypocrellin-producing genus in Shiraiaceae (Pleosporales)
}

\author{
Dong-Qin Dai', Nalin N. Wijayawardene', Li-Zhou Tang ${ }^{1,2}$, Chao Liu', \\ Li-Hong Han', Hong-Long Chu', Hai-Bo Wang', Chun-Fang Liao', Er-Fu Yang', \\ Rui-Fang Xu', Yun-Min Li ${ }^{1}$, Kevin D. Hyde $^{3}$, D. Jayarama Bhat ${ }^{4}$, Paul F. Cannon ${ }^{5}$ \\ I Center for Yunnan Plateau Biological Resources Protection and Utilization, College of Biological Resource \\ and Food Engineering, Qujing Normal University, Qujing, Yunnan 655011, China 2 State Key Laboratory \\ of Genetic Resources and Evolution, Kunming Institute of Zoology, Chinese Academy of Sciences, Kunming, \\ Yunnan 650223, China 3 Centre of Excellence in Fungal Research, Mae Fah Luang University, Chiang Rai \\ 57100, Thailand 4 No. 128/1-J, Azad Housing Society, Curca, P.O. Goa Velha 403108, India 5 Royal Bota- \\ nic Gardens, Kew, Surrey TW9 3AB, UK
}

Corresponding author: Li-Zhou Tang (biologytang@163.com); Chao Liu (liuchao_80@163.com)

Academic editor: Pedro Crous | Received 3 June 2019 | Accepted 13 August2019 | Published 28 August 2019

Citation: Dai D-Q, Wijayawardene NN, Tang L-Z, Liu C, Han L-H, Chu H-L, Wang H-B, Liao C-F, Yang E-F, Xu R-F, Li Y-M, Hyde KD, Bhat DJ, Cannon PF (2019) Rubroshiraia gen. nov., a second hypocrellin-producing genus in Shiraiaceae (Pleosporales). MycoKeys 58: 1-26. https://doi.org/10.3897/mycokeys.58.36723

\begin{abstract}
Shiraiaceae is an important family in Pleosporales (Dothideomycetes), which includes medical fungi and plant pathogens. Two hypocrellin-producing taxa, Shiraia bambusicola and a novel genus Rubroshiraia gen. nov., typified by Rubroshiraia bambusae are treated in this article. Maximum likelihood analysis, generated via RAxML (GTR+G model), using a combined SSU, LSU, TEF1 and RPB2 sequence dataset, shows that Rubroshiraia is close to Shiraia and belongs to the family Shiraiaceae. Descriptions, illustrations and a taxonomic key are provided for the genera in Shiraiaceae. Rubroshiraia morphologically differs from Shiraia in having small and dark ascostromata and filiform ascospores. Production of the ascostromatal metabolites, hypocrellin A and B, were examined by HPLC and spectrophotometer. The content of hypocrellin A and B of specimen HKAS 102255 (R. bambusae) is twice that produced by HKAS 102253 (S. bambusicola). To clarify the relationship between $R$. bambusae and Hypocrella bambusae, type material of the latter was examined and provided the illustration.
\end{abstract}

\section{Keywords}

HPLC, metabolite, new genus, phylogeny, taxonomy

Copyright Dong-Qin Dai et al. This is an open access article distributed under the terms of the Creative Commons Attribution License (CC BY 4.0), which permits unrestricted use, distribution, and reproduction in any medium, provided the original author and source are credited. 


\section{Introduction}

Liu et al. (2013) introduced the family Shiraiaceae Y.X. Liu, Zi Y. Liu \& K.D. Hyde which is typified by Shiraia Henn. and placed the family in Pleosporales Luttr. ex M.E. Barr. Ariyawansa et al. (2013) accommodated Grandigallia M.E. Barr, Hanlin, Cedeño, Parra \& R. Hern. in Shiraiaceae since it morphologically resembles Shiraia. Subsequent publications by Wijayawardene et al. $(2014,2017,2018)$ agreed with this placement and, thus, the family currently comprises two genera.

Shiraia is typified by S. bambusicola Henn. (Hennings 1900), which is parasitic on living bamboo culms and has conspicuous large, pinkish, fleshy ascostromata with multi-locules located near the periphery, fissitunicate asci and hyaline, muriform ascospores (Liu et al. 2013). S. bambusicola has been reported from temperate regions of Asia, such as China and Japan (Table 1) (Hino 1961; Li et al. 2009; Liu et al. 2013).

Shiraia has previously been placed in several families, depending on the opinions of authors. Hennings (1900) considered Shiraia to have unitunicate asci and treated as a member in the family Nectriaceae Tul. \& C. Tul. (Hypocreales, Sordariomycetes) when he established the genus. Based on its large and fleshy fruiting bodies, Shiraia was transferred to Hypocreaceae De Not by Saccardo (1902). Amano (1980) re-examined the type specimen and regarded Shiraia as having bitunicate asci and, hence, placed the genus in Pleosporaceae Nitschke (Pleosporales, Dothideomycetes). However, it was subsequently transferred to Dothideales, genera incertae sedis by Kirk et al. (2001).

Earlier classifications of Shiraia were based on morphological characters. The first attempt of DNA-based taxonomy (Cheng et al. 2004) confirmed that Shiraia belongs in Pleosporales and was phylogenetically close to species of Phaeosphaeriaceae M.E. Barr. Thus, Cheng et al. (2004) considered Shiraia as a member in Phaeosphaeriaceae. Liu et al. (2013) carried out significant studies on Shiraia taxonomy by re-examining the holotype and carrying out phylogenetic analysis, based on LSU sequence data. Liu et al. (2013) also designated an epitype of both sexual and asexual morphs and introduced Shiraiaceae in the Pleosporales.

Shiraia bambusicola has been reported as a pathogen on various bamboo species (Table 2) or as endophyte of bamboo culms (Morakotkarn et al. 2007, 2008). The bamboo genus Brachystachyum Keng is significantly affected by S. bambusicola (Table 2; Lai and Fu 2000). The holotype of S. bambusicola was recorded from a Bambusa sp. (Liu et al. 2013). Shiraia bambusicola has also been recorded on several common bamboo genera, including Fargesia Franch., Phyllostachys Sieb. et Zucc., Pleioblastus Nakai and Indosasa Mcclure (Lai and Fu 2000; Li et al. 2009). However, these hosts need to be further verified.

Shiraia bambusicola produces hypocrellins. Four hypocrellins have been extracted from the fungal stromata (Wan and Chen 1981; Kishi et al. 1991; Chen and Chen 2009). Endophytes, named as Shiraia spp., were also shown to produce hypocrellins on media (Lu et al. 2004; Morakotkarn et al. 2008; Liang et al. 2009; Zhang et al. 2014; Tong et al. 2017). The fruiting body of "Zhuhongjun" also contains hypocrellins 
Table I. Distribution of Shiraia bambusicola.

\begin{tabular}{lcc}
\hline & Distribution & References \\
\hline Country & Province & \\
China & Anhui & Li et al. (2009), Lai and Fu (2000) \\
& Guangxi & Li et al. (2009) \\
& Guizhou & Li et al. (2009) \\
& Henan & Li et al. (2009) \\
& Hubei & Li et al. (2009) \\
& Hunan & Li et al. (2009) \\
& Jiangsu & Liangxi \\
& Sichuan & Zhao and Liang (2005), Li et al. (2009) \\
& Yunan & Chen and Chen (2009), Li et al. (2009) \\
& Zhejiang & Fang et al. (2006), Chen et al. (2010) \\
& Tokyo & Li et al. (2009), Liu et al. (2013) \\
Japan & Osaka & Hino (1961), Liu et al. (2013) \\
& & Morakotkarn et al. (2007)
\end{tabular}

Table 2. List of bamboo hosts of Shiraia bambusicola.

\begin{tabular}{lc}
\hline \multicolumn{1}{c}{ Bamboo host } & References \\
\hline Brachystachyum densiflorum (Rendle) Keng & Lai and Fu (2000) \\
Brachystachyum albostriatum G.H. Lai & Li et al. (2009) \\
Brachystachyum ensiflorum (Pendle) Keng & Li et al. (2009) \\
Brachystachyum yixingense & Li et al. (2009) \\
Phyllostachys nidularia Munro & GenBank \\
Phyllostachys praecox f. prevernalis S.Y. Chen \& C.Y. Yao & GenBank \\
Pleioblastus amarus (Keng) Keng f. & GenBank \\
\hline
\end{tabular}

(Hudson et al. 1994; Huang et al. 2001). Hypocrellin seems to be an important feature when clarifying the taxa of Shiraiaceae.

A Chinese medical fungus named "Zhuhongjun" in Chinese, was identified as Hypocrella bambusae (Berk. \& Broome) Sacc. by Liu (1978), based on its conspicuous and fleshy fruiting body. However, according to our knowledge, Zhuhongjun is similar to $S$. bambusicola and unrelated to Hypocrella. Therefore, the taxonomic status of this taxon needs to be clarified.

The monotypic genus Grandigallia, collected on Polylepis sericea Wedd. (Rosaceae), was introduced by Barr et al. (1987) with G. dictyospora M.E. Barr et al. as the type species. Grandigallia dictyospora was reported from Venezuela in a locality above $3,400 \mathrm{~m}$ and the fungus was found to produce large ascostromata (3-14 cm in diam.), with bitunicate asci and dictyospores (Barr et al. 1987).

In this study, ten specimens of $S$. bambusicola and a hypocrellin producing taxon ("Zhuhongjun" in Chinese) were collected from Yunnan Province in China. Morphological and phylogenetic studies were carried out to determine the taxonomic status of these taxa. Sequences from endophytic strains, named as Shiraia spp., were also downloaded from GenBank and included in the phylogenetic analyses. The metabolite content of hypocrellin extracted from the specimens was determined by HPLC (Chem 2012). Based on the morphology and phylogenetic analyses, the hypocrellin producing taxon "Zhuhongjun" is treated as a new genus in Shiraiaceae. 


\section{Material and methods}

\section{Collecting and examination of specimens}

Bamboo culms with large, reddish to pale yellow ascostromata were collected from Yunnan, China and brought to the laboratory in 2017. Samples were examined following the methods described in Dai et al. (2017). Micro-morphological characters were examined and photographed by differential interference contrast (DIC), using a Leica DM2500 compound microscope with a Leica DMC4500 camera. Fruiting bodies were observed by stereomicroscopy using a Leica S8AP0 and photographed by HDMI 200C. Measurements were made using Tarosoft (R) Image Frame Work software. Specimens have been deposited at the herbarium of Kunming Institute of Botany, Chinese Academy of Sciences (KUN) and Herbarium Mycologicum, Academiae Sinicae (HMAS) in Beijing. Facesoffungi (Jayasiri et al. 2015) and Index Fungorum (Index Fungorum 2019) numbers were provided for new taxa. Type material of $H$. bambusae was loaned and examined from the Royal Botanic Gardens, Kew.

\section{DNA extraction, PCR amplification and sequencing}

The surface of fungal fruiting bodies was sterilised by $75 \%$ alcohol and rinsed three times in sterile water. The internal tissue with locules was cut into pieces and ground in a mortar into powder with liquid nitrogen. The powder was used to directly extract DNA with an OMEGA E.Z.N.A. Forensic DNA Kit, following the manufacturer's instructions.

ITS5 and ITS4, NS1 and NS4 (White et al. 1990) and LROR and LR5 (Vilgalys and Hester 1990) primers were used for the amplification of internal transcribed spacers (ITS), small subunit rDNA (SSU) and large subunit rDNA (LSU), respectively. Translation elongation factor $1-\alpha$ gene region (TEF 1 -alpha) and RNA polymerase II second largest subunit (RPB2) genes were amplified by using EF1983F and EF1-2218R (Rehner 2001), fRPB2-5f and fRPB2-7cr primers (Liu et al. 1999), respectively.

The final volume of the polymerase chain reaction (PCR) was prepared following Dai et al. (2017). The PCR thermal cycle programme of ITS, SSU, LSU, RPB2 and TEF 1-alpha genes amplifications were run under the same conditions as described in Dai et al. (2017). The quality of PCR products was checked by $1 \%$ Biowest agarose gel electrophoresis. Amplified PCR fragments were sequenced at Shanghai Majorbio Bio-Pharm Technology Co., Ltd. and BGI Tech Solutions Co., Ltd. (BGI-Tech), P.R. China. Generated new sequences of ITS, LSU, SSU, Rpb2 and TEF1 regions are deposited in GenBank (Table 4). 
Table 3. HPLC condition used in this study.

\begin{tabular}{lc}
\hline \multicolumn{1}{c}{ Instrument } & Condition \\
\hline Reverse phase-column & CAPCELL PAK C18 $(4.6 \mathrm{~mm} \times 25 \mathrm{~cm}, 5 \mu \mathrm{m})$ \\
Oven temp. $\left({ }^{\circ} \mathrm{C}\right)$ & 35 \\
Flow rate $(\mathrm{ml} / \mathrm{min})$ & 1 \\
Mobile phase $(\%)$ & $38 \%$ solvent A: $\mathrm{H} 2 \mathrm{O}+0.5 \%$ formic acid; $62 \%$ solvent B: acetonitrile \\
UV Absorbance $(\mathrm{nm})$ & 265 \\
Gradient elution & isocratic elution \\
Run time $(\mathrm{min})$ & $30-40$ \\
\hline
\end{tabular}

Table 4. List of newly generated sequences with their culture collection numbers and GenBank accession numbers.

\begin{tabular}{|c|c|c|c|c|c|c|}
\hline \multirow[t]{2}{*}{ Organism } & \multirow[t]{2}{*}{ Specimen voucher } & \multicolumn{5}{|c|}{ GenBank accession numbers } \\
\hline & & ITS & LSU & SSU & TEF & RPB2 \\
\hline \multirow[t]{10}{*}{ Shiraia bambusicola } & HKAS102253 & MK804668 & MK804648 & MK804694 & MK819208 & MK819228 \\
\hline & HKAS102254 & MK804669 & MK804649 & MK804695 & MK819209 & MK819229 \\
\hline & HKAS102257 & MK804670 & MK804650 & MK804696 & MK819210 & MK819230 \\
\hline & HKAS102261 & MK804671 & MK804651 & MK804697 & MK819211 & MK819231 \\
\hline & HKAS102262 & MK804672 & MK804652 & MK804698 & MK819212 & MK819232 \\
\hline & HKAS102263 & MK804673 & MK804653 & MK804699 & MK819213 & MK819233 \\
\hline & HKAS102264 & MK804674 & MK804654 & MK804700 & MK819214 & MK819234 \\
\hline & HKAS102265 & MK804675 & MK804655 & MK804701 & MK819215 & MK819235 \\
\hline & HKAS102266 & MK804676 & MK804656 & MK804702 & MK819216 & MK819236 \\
\hline & HKAS102267 & MK804677 & MK804657 & MK804703 & MK819217 & MK819237 \\
\hline \multirow[t]{10}{*}{ Rubroshiraia bambusae } & HKAS102255 & MK804678 & MK804658 & MK804704 & MK819218 & \\
\hline & HKAS102256 & MK804679 & MK804659 & MK804705 & MK819219 & \\
\hline & HKAS102260 & MK804680 & MK804660 & MK804706 & MK819220 & \\
\hline & HKAS102268 & MK804681 & MK804661 & MK804707 & MK819221 & \\
\hline & HKAS102269 & MK804682 & MK804662 & MK804708 & MK819222 & \\
\hline & HKAS102270 & MK804683 & MK804663 & MK804709 & MK819223 & \\
\hline & HKAS102271 & MK804684 & MK804664 & MK804710 & MK819224 & \\
\hline & HKAS102272 & MK804685 & MK804665 & MK804711 & MK819225 & \\
\hline & HKAS102273 & MK804686 & MK804666 & MK804712 & MK819226 & \\
\hline & HKAS102274 & MK804687 & MK804667 & MK804713 & MK819227 & \\
\hline
\end{tabular}

The holotype specimen is highlighted in bold. Abbreviations: HKAS: herbarium of Kunming Institute of Botany, Chinese Academy of Sciences.

\section{Phylogenetic analysis}

The BLAST searches in GenBank, using LSU and ITS sequence data were carried out to obtain the close strains. Additional sequences were downloaded from GenBank based on recent publications (Liu et al. 2017).

Single gene sequence alignments were carried out with MAFFT v. 7.215 (Katoh and Standley 2013, http://mafft.cbrc.jp/alignment/server/index.html) and edited manually when necessary in BioEdit v. 7.0 (Hall 2004). The alignments of LSU, SSU, Rpb2 and TEF1 regions were combined in MEGA6 version 6.0 (Tamura et al. 2013).

Maximum-likelihood (ML) analyses, including 1000 bootstrap replicates, were run using RAxMLGUI v.1.0. (Stamatakis 2006; Silvestro and Michalak 2011). Align- 
ments in PHYLIP format were exchanged and loaded from the website (http://sing. ei.uvigo.es/ALTER/). The online tool Findmodel (http://www.hiv.lanl.gov/content/ sequence/findmodel/findmodel.html) was used to determine the best nucleotide substitution model for each partition data.

Maximum-parsimony (MP) analyses were carried out in PAUP v. 4.0b10 (Swofford 2002) with 1000 replications. Maxtrees were set to 1000, branches of zero length were collapsed and all multiple equally most parsimonious trees were saved. The robustness of the most parsimonious trees was evaluated from 1000 bootstrap replications (Phillips et al. 2013).

Bayesian analyses were performed using MrBayes v. 3.0b4 (Ronquist and Huelsenbeck 2003). The model of evolution was performed using MrModeltest v. $2.2(\mathrm{Ny}-$ lander 2004). Posterior Probabilities (PP) (Rannala and Yang 1996; Zhaxybayeva and Gogarten 2002) were determined by Markov Chain Monte Carlo sampling (MCMC) in MrBayes v. 3.0b4 (Huelsenbeck and Ronquist 2001). Six simultaneous Markov chains were run for 1,000,000 generations and trees were sampled every $100^{\text {th }}$ generation. The burn-in was set to 0.25 and the run was automatically stopped when the average standard deviation of split frequencies reached below 0.01 (Maharachchikumbura et al. 2015).

Trees were visualised with TreeView (Page 1996) or FigTree v. 1.4.0 (http://tree. bio.ed.ac.uk/software/figtree/) and, additionally, layouts were done with Adobe Illustrator CS v. 5. Maximum-likelihood bootstrap values (MLBP) and Maximum-parsimony bootstrap values (MPBP) equal to or greater than $50 \%$ are given for each tree. Bayesian posterior probabilities (BYPP) $>0.90$ are indicated as thickened lines. The sequences used in this study are listed in Table 1 . The combined alignment and phylogenetic tree were submitted at TreeBASE (http://purl.org/phylo/treebase/phylows/ study/TB2:S24345).

\section{HPLC profiling}

Standards of hypocrellin A and hypocrellin B were purchased from Shanghai Tauto Biotech CO., Ltd. (http://www.tautobiotech.com) and used as received. Their purity is $\geq 98 \%$ (HPLC) and their structures are redrawn based on references (Wan and Chen 1981; Morakotkarn et al. 2008) and shown in Figure 1. The dry powder of ascostromata of S. bambusicola (HKAS102266) and "Zhuhongjun" (HKAS102270) was extracted followed the methods described by Stadler et al. (2001) and accurately weighed to $0.5 \mathrm{~g}$ and added to $25 \mathrm{ml}$ of methanol and sonicated for $30 \mathrm{~min}$. Semi-preparative HPLC was performed on an Agilent 1260 apparatus equipped with a UV detector and a CAPCELL PAK C18 (Agilent, $4.6 \mathrm{~mm} \times 25 \mathrm{~cm}, 5 \mu \mathrm{m}$ ) column, with $38 \%$ solvent A: $\mathrm{H}_{2} \mathrm{O}+0.5 \%$ formic acid; $62 \%$ solvent $\mathrm{B}$ : acetonitrile, isocratic elution, $\mathrm{UV} / \mathrm{Vis}$ the detection in the range of $265 \mathrm{~nm}$ (Table 3). The UV-Vis spectra were recorded at room temperature on a Perkin-Elmer Lambda 900 spectrophotometer (Fig. 5). 


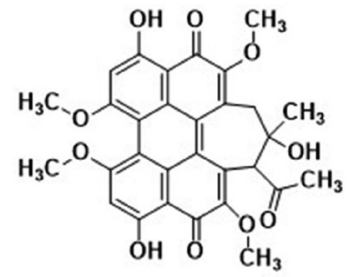

A

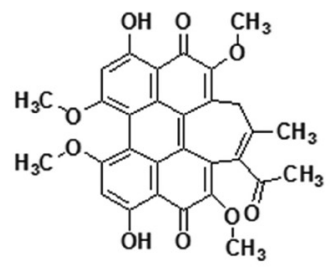

B

Figure I. Chemical structures of hypocrellin A and hypocrellin B. A hypocrellin A B hypocrellin B.

\section{Results}

\section{Phylogeny}

To clarify the family placement of newly established taxa, maximum likelihood phylogenetic analysis was generated from RAxML (GTR+G model), based on combined SSU, LSU, TEF1 and RPB2 sequences data (Fig. 2). The combined alignment comprised 4025 characters including gaps for 127 ingroup taxa and one outgroup taxon Dothidea insculpta (CBS 189.58). Based on the phylogenetic tree in Fig. 2, the new collections cluster within family Shiraiaceae with high bootstrap support (96/1.00 MLBS/BSPP) and emerge as two groups, which are S. bambusicola lineage and a new clade named as $R$. bambusae in this paper. Shiraia and Rubroshiraia have more or less similar ascostromata and both of them can produce the metabolite hypocrellins. However, they can be phylogenetically distinguished with high bootstrap support (100/1.00 MLBS/BSPP) (Fig. 2). Grandigallia has not been included in phylogenetic analysis as it is lacking sequences in the GenBank. However, the new taxa can be morphologically distinguished from it. Shiraiaceae is phylogenetically close with family Phaeosphaeriaceae in Pleosporales and this has been confirmed by Liu et al. (2013).

To clarify the relationship between endophytic strains named as shiraia-like (Shiraia spp.) and Shiraiaceae, a phylogenetic tree was constructed (RAxML (GTR+G model), based on combined LSU and ITS sequences data and compared. The combined alignment comprises 1442 characters including gaps for 57 ingroup taxa and one outgroup taxon Pleospora herbarum (CBS 191.86). Of the 1442 characters of the combined matrix, 1116 were constant and 220 were parsimony informative. The endophytic strains separated into two lineages (Group A and group B) forming at the base clade of Shiraiaceae (Fig. 3). Several strains in group A ca. JP7, JP93, JP232, JP256, SUPER-H168, A8 and ML-2004, isolated from bamboo tissue can produce hypocrellins in media (Lu et al. 2004; Morakotkarn et al. 2008; Liang et al. 2009; Cai et al. 2011; Zhang et al. 2014). However, no hypocrellins were detected from Group B, which included three Japanese strains viz. JP119, JP151 and JP185 (Morakotkarn et al. 2008). 


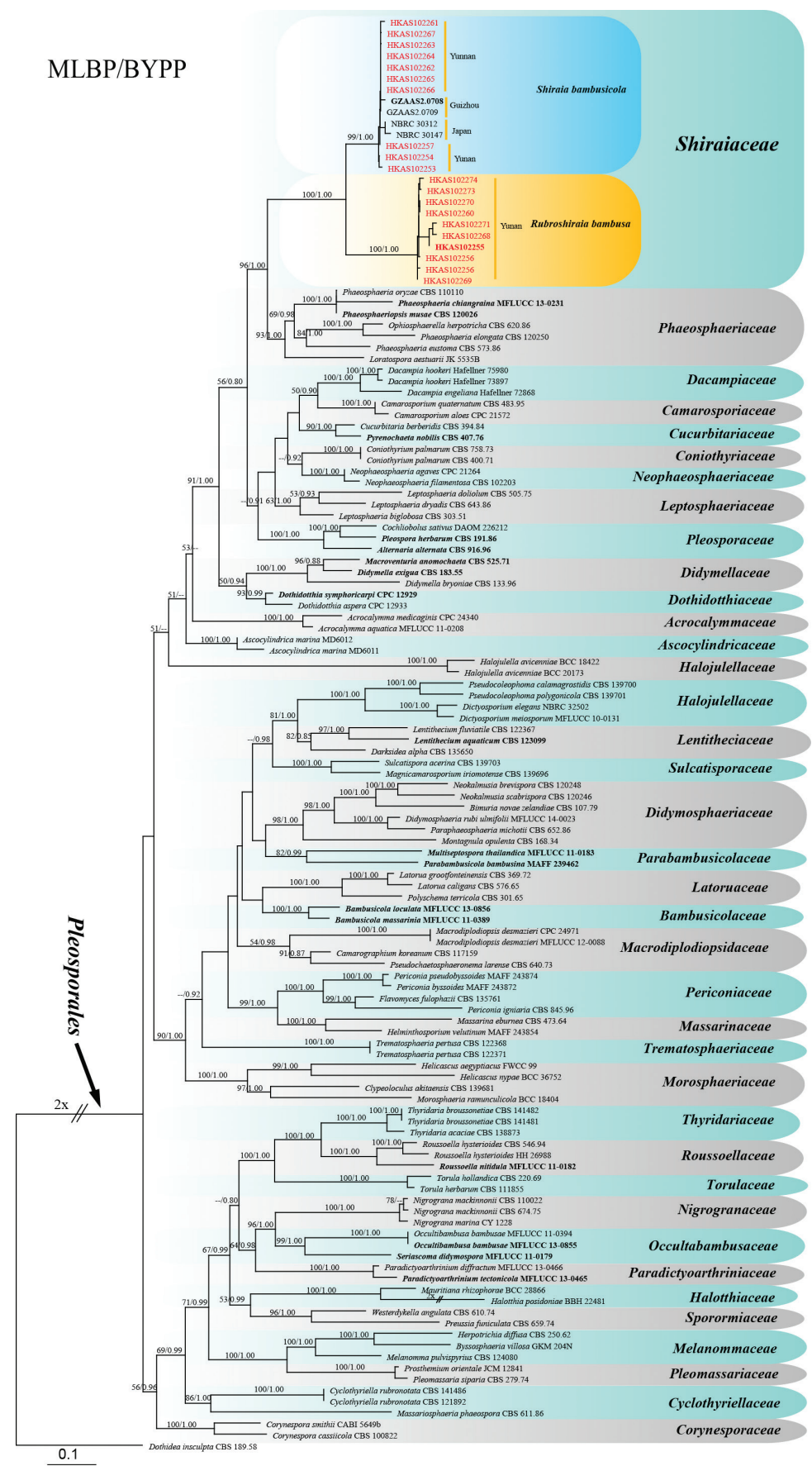

Figure 2. Maximum likelihood phylogenetic tree generated from RAxML (GTR+G model), based on combined LSU, SSU, TEF1 and RPB2 sequences data. ML values (MLBP) (> 50\%), resulting from 1000 bootstrap replicates and Bayesian posterior probabilities (BYPP) greater than 0.90 , are given at the nodes. The original isolate numbers' codes are noted after the species names. The tree is rooted to Dothidea insculpta (CBS 189.58). Ex-type or ex-epitype strains are in bold. Newly generated strains are in red and the new genus is in yellow background. 


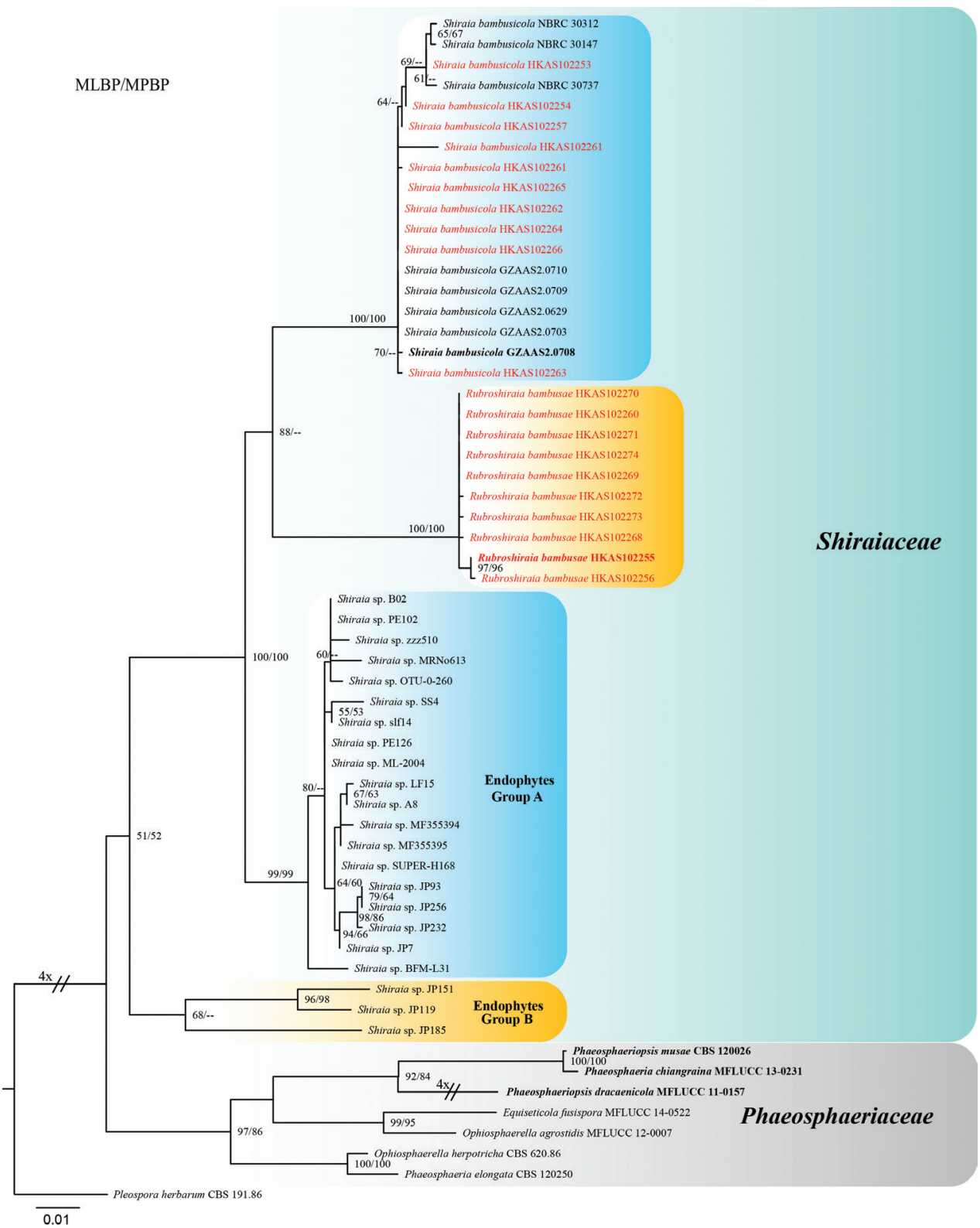

Figure 3. Maximum likelihood phylogenetic tree generated from RAxML (GTR+G model), based on combined LSU and ITS sequences data. ML and MP values (MLBP/MPBP) (> 50\%), resulting from 1000 bootstrap replicates, are given at the nodes. The original isolate numbers' codes are noted after the species names. The tree is rooted to Pleospora herbarum (CBS 191.86). Ex-type or ex-epitype strains are in bold. Newly generated strains are in red. 


\section{Metabolites production}

Stromatal extracts from specimens of S. bambusicola (HKAS102266) and R. bambusae (HKAS102270) contained high quantities of hypocrellin A (304.03 ng/ul and 790.86 ng/ul, respectively). Stromatal extracts from specimens of $S$. bambusicola contained $42.55 \mathrm{ng} / \mathrm{ul}$ hypocrellin $\mathrm{B}$, whereas $R$. bambusae produces a higher quantity (204.60 $\mathrm{ng} / \mathrm{ul})$. The HPLC profiles of $S$. bambusicola and $R$. bambusae are depicted in Figure 4. The UV spectrum of the standards and of hypocrellin A and B from the samples $(S$. bambusicola HKAS 102253 and R. bambusae HKAS 102255) were recorded in alcohol and shown in Figure 5.

\section{Taxonomy}

Shiraiaceae Y.X. Liu, Zi Y. Liu \& K.D. Hyde, Phytotaxa 103(1): 53 (2013)

Index Fungorum number: IF803884

Facesoffungi number: FoF 06202

Notes. The family Shiraiaceae was introduced by Liu et al. (2013) with a single genus and later Grandigallia was added to this family by Ariyawansa et al. (2013). In previous studies, Shiraiaceae was closely related with Phaeosphaeriaceae and their distinction was questionable (Cheng et al. 2004, Liu et al. 2013). However, our multi-gene analyses (Fig. 2) clearly indicate that Shiraiaceae and Phaeosphaeriaceae are distinct. Evidence is also borne out by the fact the Phaeosphaeriaceae have single ascostromata (Phookamsak et al. 2014), while in Shiraiaceae, ascostromata have multiple ascomata. Moreover, Shiraiaceae produces a high quantity of hypocrellins and no such metabolites, secreted by Phaeosphaeriaceae, were reported as far as we know (Phookamsak et al. 2014). In this study, the third genus (i.e. Rubroshiraia) is introduced to the family and produces hypocrellins. The endophytic strains in the phylogenetic tree in Figure (2) probably can be named as new genera, once the types are selected. Thus, currently three genera are placed in Shiraiaceae.

Type genus. Shiraia Henn., Bot. Jb. 28(3): 274 (1900).

Type species. S. bambusicola Henn., Bot. Jb. 28(3): 274 (1900).

Shiraia bambusicola Henn., Bot. Jb. 28(3): 274 (1900)

Fig. 6

Index Fungorum number: IF158454

Facesoffungi number: FoF 06203

Description. Parasitic on living branches of bamboo. Sexual morph: Ascostromata 1-6 cm long $\times 1-4 \mathrm{~cm}$ wide, solitary, superficial, subglobose, long ellipsoid to irregular, tuberculate, fleshy, white to pinkish, with locules lining the periphery, 

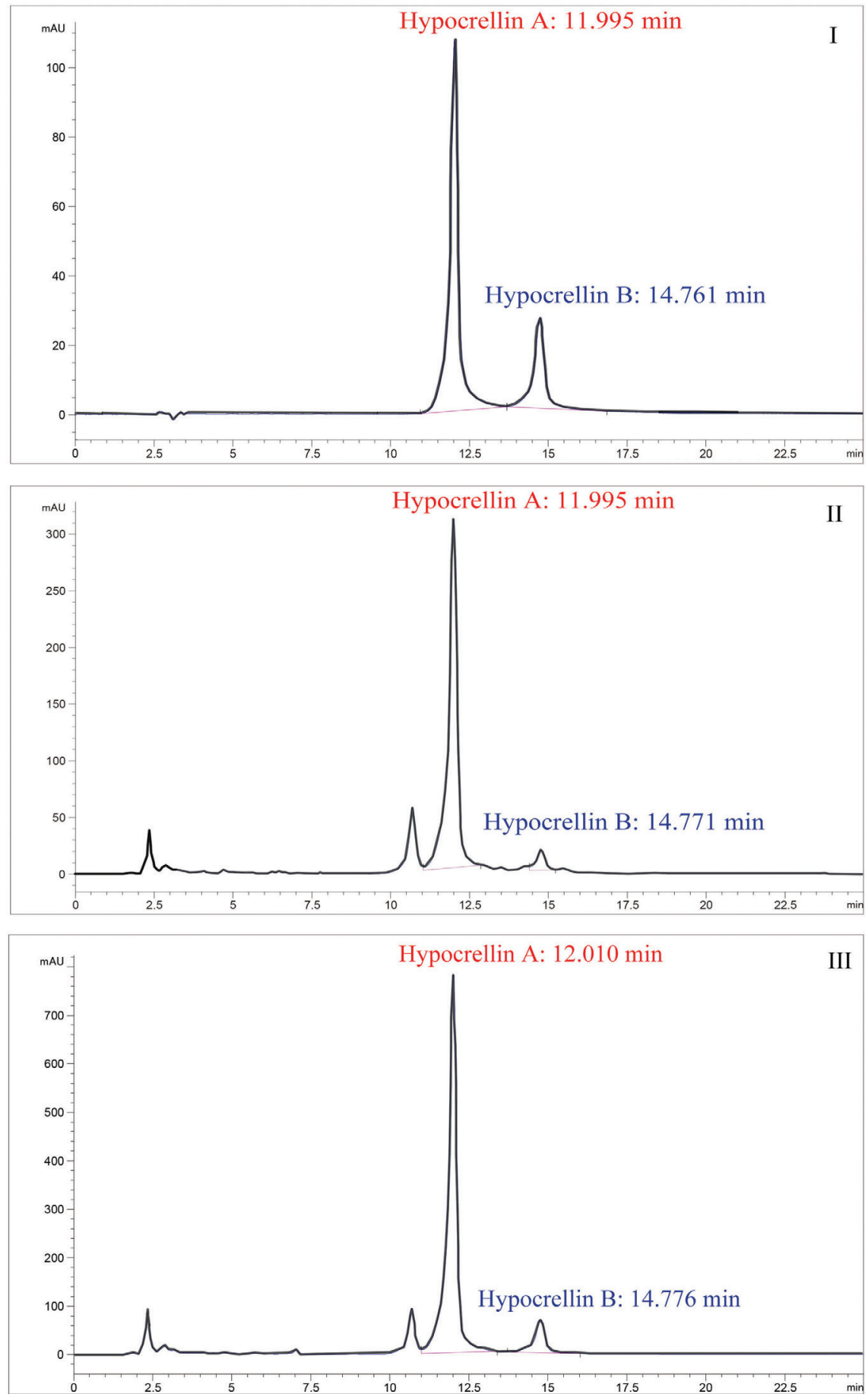

Figure 4. Hypocrellin A and hypocrellin B HPLC-UV profiles $(265 \mathrm{~nm})$ of standards and stromatal HPLC-UV profiles (265 nm) of specimens of Shiraia bambusicola (HKAS 102253) (II) and Rubroshiraia bambusae (HKAS 102255) (III) and DAD spectra of major metabolites. 


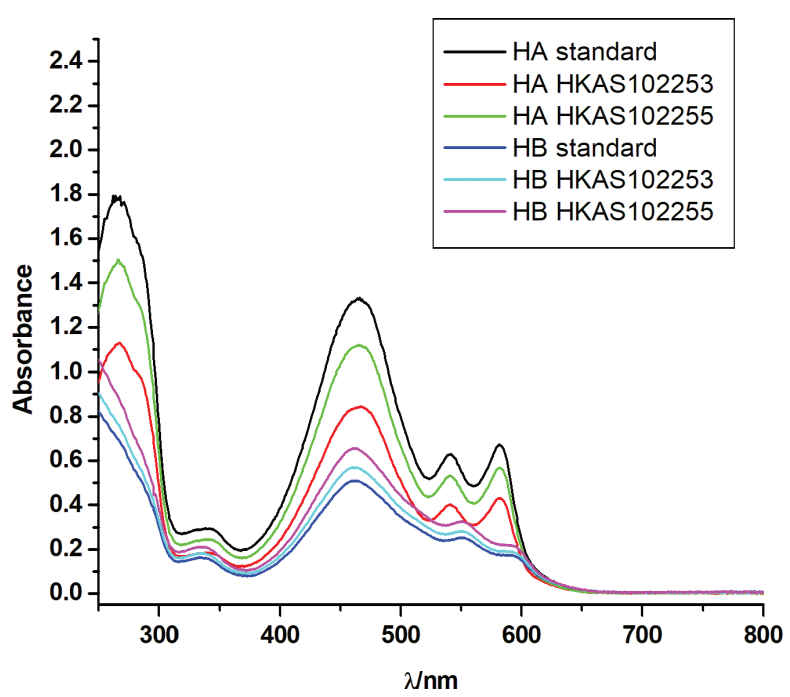

Figure 5. The UV spectrum of the standards and of hypocrellin A and B from the samples (Shiraia bambusicola HKAS 102253 and Rubroshiraia bambusae HKAS 102255) were recorded in alcohol at room temperature. HA: hypocrellin A, HB: hypocrellin B.

with dark ostiolate points appearing on surface. Ascostromatic tissue thick, pinkish, composed of wide, woven hyphae of textura intricata. Locules in vertical section 370-700 $\mu \mathrm{m}$ high $\times 370-700 \mu \mathrm{m}$ diam. $(\bar{x}=541 \times 513 \mu \mathrm{m}, \mathrm{n}=20)$, globose to subglobose, immersed in the peripheral layer of ascostromata, with 100-200 $\mu \mathrm{m}$ wide ostioles. Peridium $20-45 \mu \mathrm{m}$ thick, composed of several layers of hyaline to light brown, small cells of textura angularis to textura intricata. Hamathecium composed of interthecial, hyaline septate, branched pseudoparaphyses, 1-2.5 $\mu \mathrm{m}$ wide. Asci $200-370 \times 20-35 \mu \mathrm{m}(\bar{x}=291.6 \times 26.6 \mu \mathrm{m}, \mathrm{n}=20)$, 4-6-spored, thick-walled, bitunicate, fissitunicate, cylindrical, short-pedicellate, with an ocular chamber. Ascospores 50-77 $\times 15-24 \mu \mathrm{m}(\bar{x}=62.3 \times 18.1 \mu \mathrm{m}, \mathrm{n}=20)$, 1-seriate, overlapped, fusiform, muriform, hyaline, with 7 transverse septa, constricted at the septum, smooth-walled. Asexual morph: Conidiomata 200-500 $\mu \mathrm{m}$ high, $300-400 \mu \mathrm{m}$ wide, loculate, forming within ascostromata, globose to subglobose or irregular. Wall of locules $20-40 \mu \mathrm{m}$ thick, composed of several layers of hyaline to light brown, small cells of textura intricata. Conidiophores reduced to conidiogenous cells. Conidiogenous cells 3-6 $\times 2-3 \mu \mathrm{m}(\bar{x}=4.7 \times 2.1 \mu \mathrm{m}, \mathrm{n}=10)$, blastic, cylindrical, hyaline, smooth-walled. Conidia $60-80 \times 19-25 \mu \mathrm{m}(\bar{x}=75.4 \times 23.1$ $\mu \mathrm{m}, \mathrm{n}=20$ ), fusiform, muriform, hyaline, with irregularly transverse and longitudinal septa, straight to curved, smooth-walled.

Culture characters. Colonies growing slowly, attaining $30 \mathrm{~mm}$ diam. after 2 weeks at $27^{\circ} \mathrm{C}$ under dark, circular, with even margin, floccose at the centre, drift white at margin, light greenish at centre, dark from below.

Material examined. CHINA, Yunnan province, Lijiang, on living branches of Brachystachyum densiflorum (Rendle) Keng, 3 May 2017, Dong-Qin Dai, DDQ00409 

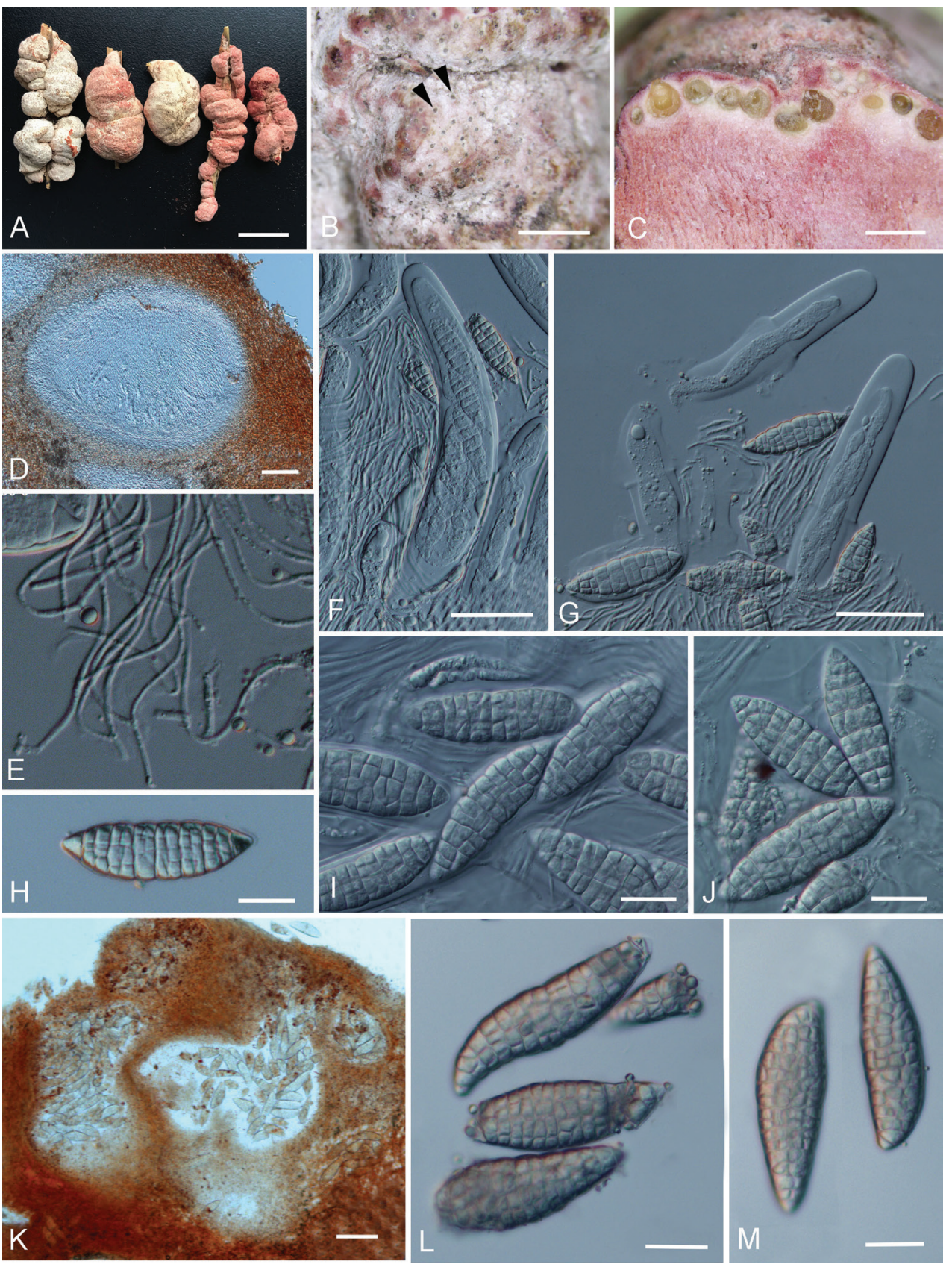

Figure 6. Shiraia bambusicola A-J sexual morph A fruiting bodies (HKAS102253, HKAS102254, HKAS102257, HKAS102261, HKAS102262) B-J photographs from material HKAS102253 B Surface of ascostromata showing the dark openings of ostiole $\mathbf{C}$ vertical section of ascostromata $\mathbf{D}$ vertical section of locule $\mathbf{E}$ pseudoparaphyses $\mathbf{F}, \mathbf{G}$ asci (G Showing the fissitunicate asci) $\mathbf{H}-\mathbf{J}$ ascospores $\mathbf{K}-\mathbf{M}$ asexual morph $\mathbf{K}$ vertical section of asexual locules $\mathbf{L}-\mathbf{M}$ conidia. Scale bars: $2 \mathrm{~cm}(\mathbf{A}), 5 \mathrm{~mm}(\mathbf{B}), 1 \mathrm{~mm}(\mathbf{C})$, $100 \mu \mathrm{m}(\mathbf{D}, \mathbf{K}), 50 \mu \mathrm{m}(\mathbf{F}, \mathbf{G}), 20 \mu \mathrm{m}(\mathbf{H}-\mathbf{J}, \mathbf{L}, \mathbf{M})$. 
(HKAS102253), Ibid. (duplicate specimen deposited in HMAS 290446), Ibid. DDQ00410 (HKAS102254), Ibid. DDQ00413 (HKAS102257), Ibid. 10 June 2017, Dong-Qin Dai, DDQ00418 (HKAS102261), Ibid. DDQ00419 (HKAS102262), Ibid. DDQ00420 (HKAS102263), Ibid. DDQ00421 (HKAS102264), Ibid. DDQ00422 (HKAS102265), Ibid. DDQ00423 (HKAS102266), Ibid. DDQ00424 (HKAS102267).

Notes. Shiraia bambusicola was erected by Hennings (1900), based on a collection from Japan. Liu et al. (2013) re-examined the holotype with 1-2.5 cm wide ascostromata, which is smaller than the new collections ( $1-4 \mathrm{~cm}$ wide in ascostromata) in China. The holotype has large ascospores compared with the new specimens in this study $(75-125 \times 23-47 \mu \mathrm{m}$ vs. 50-77 $\times 15-24 \mu \mathrm{m})$. The epitype designated by Liu et al. (2013) which has similar-sized $(50-77 \times 15-24 \mu \mathrm{m})$ ascospores and similar ITS sequence, as in our new collections.

\section{Other genera included}

\section{Grandigallia M.E. Barr et al., Mycotaxon 29: 196. 1987.}

Index Fungorum number: IF12090

Facesoffungi number: FoF 06204

Description. See Ariyawansa et al. (2013).

Type species. Grandigallia dictyospora M.E. Barr et al., Mycotaxon 29: 196 (1987)

Notes. The monotypic genus Grandigallia was introduced by Barr (1987) and is typified by $G$. dictyospora. The fungus infects branches of Polylepis sericea Wedd. (Rosaceae) and produces conspicuous (3-14 cm in diam.) and black ascostromata. Grandigallia closely resembles Shiraia in having muriform ascospores, however, it differs by its black and larger ascostromata. Kirk et al. (2008) and Lumbsch and Huhndorf (2010) placed Grandigallia in Dothideomycetes, genera incertae sedis. Ariyawansa et al. (2013) re-examined the type material and transferred it to Shiraiaceae in Pleosporales. Wijayawardene et al. $(2014,2017,2018)$ accepted this placement.

\section{Rubroshiraia D.Q. Dai \& K.D. Hyde, gen. nov.}

Index Fungorum number: IF556564

Facesoffungi number: FoF 06205

Etymology. The epithet "Rubro" means red colour referring to reddish ascotromata similar to the genus Shiraia.

Description. Parasitic on living branches of bamboo. Sexual morph: Ascostromata solitary, superficial, globose to subglobose, fleshy, reddish, with locules lining the periphery, with dark ostiolate tips appearing on surface. Ascostromatic tissue thick, 
pinkish, composed of wider woven hyphae of textura intricata. Locules globose to subglobose, immersed in the peripheral layer of ascostromata, with narrow ostiolate openings. Peridium composed of several layers of hyaline to dark brown, small cells of textura angularis to textura intricata. Hamathecium of interthecial, hyaline, septate, branched pseudoparaphyses above asci. Asci 8-spored, thick-walled, bitunicate, fissitunicate, cylindrical, short-pedicellate, with an ocular chamber. Ascospores spirally arranged in asci, filiform, hyaline, with transverse septa, smooth-walled. Asexual morph: Undetermined.

Type species. R. bambusae D.Q. Dai \& K.D. Hyde.

Notes. The hypocrellin-producing fungus $R$. bambusae is a well-known taxon used in Chinese traditional medicine which is called "Zhuhongjun" or "Zhuxiaorouzhuojun" in Chinese. However, without molecular data, it was wrongly named as H. bambusae (Liu 1978).

Hypocrella bambusae was combined by Saccardo (1878), based on its linear asci and filiform ascospores. Index Fungorum (2019) lists its basionym as Hypocrea bambusae Berk. \& Broome, which was collected on the inflorescences of bamboo in Sir Lanka and had linear asci and filiform ascospores (Berkeley and Broome 1875). Liu (1978) recorded a well-known Chinese medicinal ascomycete, producing $0.7-1.5 \mathrm{~mm}$ diam., hemispheric and reddish stromata with multi-locules, cylindrical asci and filiform ascospores which are spirally arranged and more than $250 \mu \mathrm{m}$ long on bamboo culms. Liu (1978) identified this fungus as $H$. bambusae, probably based on its cylindrical asci and filiform ascospores. In addition, species of Hypocrella usually produce perithecial ascomata (Saccardo 1878). To our knowledge, no fungal records or herbal medicine like that described in Liu (1978) occur in Sir Lanka. Moreover, based on the examination of type material of Hypocrea bambusae, it has smaller $(0.1 \mathrm{~cm}$ vs. $0.7-1.5 \mathrm{~mm}$ in diam.) and black stromata, unitunicate asci and ascospores are in a single fascicle but not significantly helically coiled (Fig. 7). Hence, we conclude that Liu (1978) made a wrong identification.

New collections of "Zhuhongjun" were collected and sequenced. The phylogenetic analyses showed it belongs to Shiraiaceae and is separate from Shiraia with high bootstrap support (100/1.00 MLBS/BSPP) (Fig. 2). Grandigallia has not been included in the phylogenetic tree as it is lacking gene sequences in the GenBank (retrieved date: 13 May 2019). However, Grandigallia can be morphologically distinguished from the new taxon in having black ascostromata and muriform ascospores (Barr 1987; Ariyawansa et al. 2013). Thus, this fungus is introduced as $R$. bambusae gen. et sp. nov in this study.

Rubroshiraia bambusae is often confused with $S$. bambusicola by Chinese traditional folk residents, probably because of the similarity of their ascostromata, parasitism on bamboo host and similar efficacy of medical treatment. However, it differs from S. bambusicola by its smaller sized ascostromata $(0.7-1.2 \mathrm{~cm}$ long $\times 0.7-1 \mathrm{~cm}$ wide vs. $1-6 \mathrm{~cm}$ long $\times 1-4$ $\mathrm{cm}$ wide) and distinct ascospores (filiform ascospores vs. fusiform and muriform ones). Both of the above species can produce the metabolites hypocrellin $\mathrm{A}$ and $\mathrm{B}$, whereas $R$. bambusae contains almost double the content compared to S. bambusicola (Fig. 4). 


\section{Rubroshiraia bambusae D.Q. Dai \& K.D. Hyde, sp. nov.}

Fig. 7

Index Fungorum number: IF556564

Facesoffungi number: FoF 06206

Etymology. Refers the bamboo host.

Holotype. HKAS102255.

Description. Parasitic on living branches of bamboo. Sexual morph: Ascostromata $0.7-1.5 \mathrm{~cm}$ long $\times 0.7-1.3 \mathrm{~cm}$ wide, solitary, superficial, globose to subglobose, fleshy, reddish, with locules lining the periphery, with dark ostiolate points appearing on the surface. Ascostromatic tissue thick, pinkish, composed of wider woven hyphae of textura intricata. Locules in vertical section 800-1800 $\mu \mathrm{m}$ high $\times 1000-2000 \mu \mathrm{m}$ diam. $(\bar{x}=1289.4 \times 1368.8 \mu \mathrm{m}, \mathrm{n}=20)$, globose to subglobose, immersed in the periphery layer of ascostromata, with $250-500 \mu \mathrm{m}$ wide $\times 450-550 \mu \mathrm{m}$ high ostioles. Peridium 20-35 $\mu \mathrm{m}$ thick, composed of several layers of hyaline to dark brown, small cells of textura angularis to textura intricata. Hamathecium of interthecial, hyaline septate, branched pseudoparaphyses, 1-3 $\mu \mathrm{m}$ wide. Asci 660-800 $\times 45-55 \mu \mathrm{m}$ $(\bar{x}=751.6 \times 49.5 \mu \mathrm{m}, \mathrm{n}=20), 8$-spored, thick-walled, bitunicate, fissitunicate, cylindrical, short-pedicellate, with an ocular chamber. Ascospores 600-750 $\times 5.5-11 \mu \mathrm{m}$ $(\bar{x}=728.8 \times 9.1 \mu \mathrm{m}, \mathrm{n}=20)$, spirally arranged in asci, filiform, hyaline, with $15-18$ transverse septa, smooth-walled. Asexual morph: Undetermined.

Material examined. CHINA, Yunnan, Dali, on living branches of Fargesia spathacea Franch, 13 May 2017, Dong-Qin Dai, DDQ00411 (HKAS102255, holotype), Ibid. (HMAS 290447, isotype), Ibid. DDQ00412 (HKAS102256), Ibid. DDQ00416 (HKAS102260), Ibid. 20 June 2017, Dong-Qin Dai, DDQ00425 (HKAS102268), Ibid. DDQ00426 (HKAS102269), Ibid. DDQ00427 (HKAS102270), Ibid. DDQ00428 (HKAS102271), Ibid. DDQ00429 (HKAS102272), Ibid. DDQ00430 (HKAS102273), Ibid. DDQ00431 (HKAS102274).

Key for distinguishing genera in Shiraiaceae

1 Parasitising bamboo branches, ascostromata are white to reddish 2

- Parasitising Rosaceae branches, ascostromata are black Grandigallia

2 Ascospores muriform Shiraia

- Ascospores filiform. Rubroshiraia

Since the familial placement of $H$. bambusae is controversial in different studies (Berkeley and Broome 1875, Saccardo 1878, Liu 1978), we re-studied the isotype. Based on morphology, we conclude that it has unitunicate asci thus related to Sordariomycetes. 

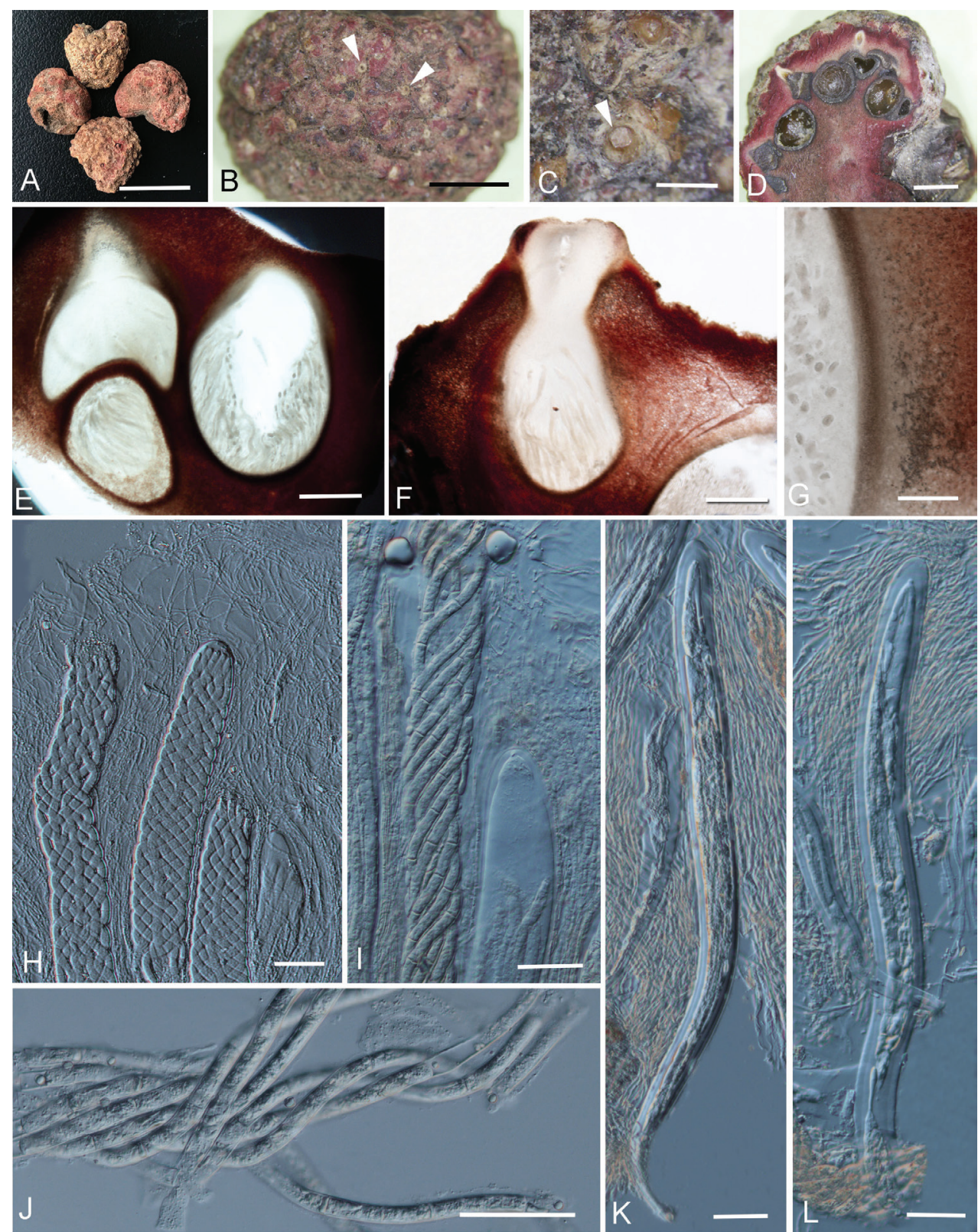

Figure 7. Rubroshiraia bambusae (HKAS102255, holotype) A fruiting bodies B, C surface of ascostromata showing the openings of ostiole $\mathbf{D}$ vertical section of ascostromata $\mathbf{E}, \mathbf{F}$ vertical section of locule $\mathbf{G}$ peridium of locule $\mathbf{H}$ asci and pseudoparaphyses $\mathbf{I}$ asci and asci ocular chamber $\mathbf{J}$ ascospores $\mathbf{K}, \mathbf{L}$ immature asci. Scale bars: $1 \mathrm{~cm}(\mathbf{A}), 25 \mathrm{~mm}(\mathbf{B}), 2 \mathrm{~mm}(\mathbf{C}, \mathbf{D}), 500 \mu \mathrm{m}(\mathbf{E}, \mathbf{F}), 200 \mu \mathrm{m}(\mathbf{G}), 50 \mu \mathrm{m}(\mathbf{H}-\mathbf{L})$. 


\section{Hypocrella bambusae (Berk. \& Broome) Sacc. 1878}

Fig. 8

Index Fungorum number: IF160297

Basionym. Hypocrea bambusae Berk. \& Broome, 1873

Description. Parasitic on living inflorescence of bamboo. Sexual morph: Stro$\boldsymbol{m a t a}$ around $0.14 \mathrm{~cm}$ diam., $0.06 \mathrm{~cm}$ high, solitary, superficial, subglobose, fleshy to coriaceous, black, with around 20 perithecia lining the periphery, with ostioles slightly raised above stroma surface. Stromatic tissue thick, brown to dark brown. Perithecia in vertical section around $100 \mu \mathrm{m}$ diam., $200 \mu \mathrm{m}$ high, pyriform, immersed in the periphery layer of stromata. Asci more than $220 \mu \mathrm{m}$ long, 5-6 $\mu \mathrm{m}$ diam., 8-spored, unitunicate, cylindrical, with a glassy refractive cap around $3 \mu \mathrm{m}$ from apex to base. Ascospores around $180 \mu \mathrm{m}$ long, 1-1.5 $\mu \mathrm{m}$ diam., in a single fascicle but not significantly helically coiled, filiform, hyaline, with 9-10 transverse septa, with rounded ends, smooth-walled. Asexual morph: Undetermined.

Material examined. SRI LANKA, on inflorescence of bamboo, January 1855, G.H.K. Thwaites s.n. (ex herb. M.J. Berkeley), K(M)52469, isotype.

Notes. This taxon has typical morphology of the Clavicipitaceae, which is pyriform perithecia with a gradually tapering upper part and cylindrical asci with a glassy refractive cap. New collections are required and need to be sequenced to clarify its placement.

\section{Discussion}

Members of the family Shiraiaceae are distributed from Asia to South America but so far reported only from three countries, viz. China, Japan and Venezuela (Barr et al. 1987; Liu et al. 2013). The family comprises three genera, i.e. Grandigallia, Rubroshiraia and Shiraia wherein the former genus is lacking DNA sequences and, thus in here, we did not include it in the molecular analyses (Figs 2 and 3). These genera show the typical characters of Shiraiaceae, viz. conspicuous large, tuberculate, fleshy and multi-loculate ascostromata producing bitunicate asci. Shiraia bambusicola has various types of ascostromata, such as subglobose to tuberculate with white to pinkish colours (Fig. 6). However, the phylogenetic analysis shows these specimens with different types of ascostromata belong to same species (Figs 2 and 3). Thus, we assume that the different shapes of ascostromata are because of the host and different environment conditions.

Stromatal methanol extracts of Rubroshiraia and Shiraia contain Hypocrellins (Fig. 4). However, so far no extracts have been reported from Grandigallia. Fresh material of Grandigallia is essential to determine the metabolites. Rubroshiraia has darker reddish ascostromata compared with Shiraia, probably because its stromatal methanol extracts contain larger quantity of hypocrellins. Some endophytes, named as Shiraialike fungi, are known to produce hypocrellins on media. They were isolated from different parts of bamboo, such as seeds, nods and internodes (Lu et al. 2004; Mora- 


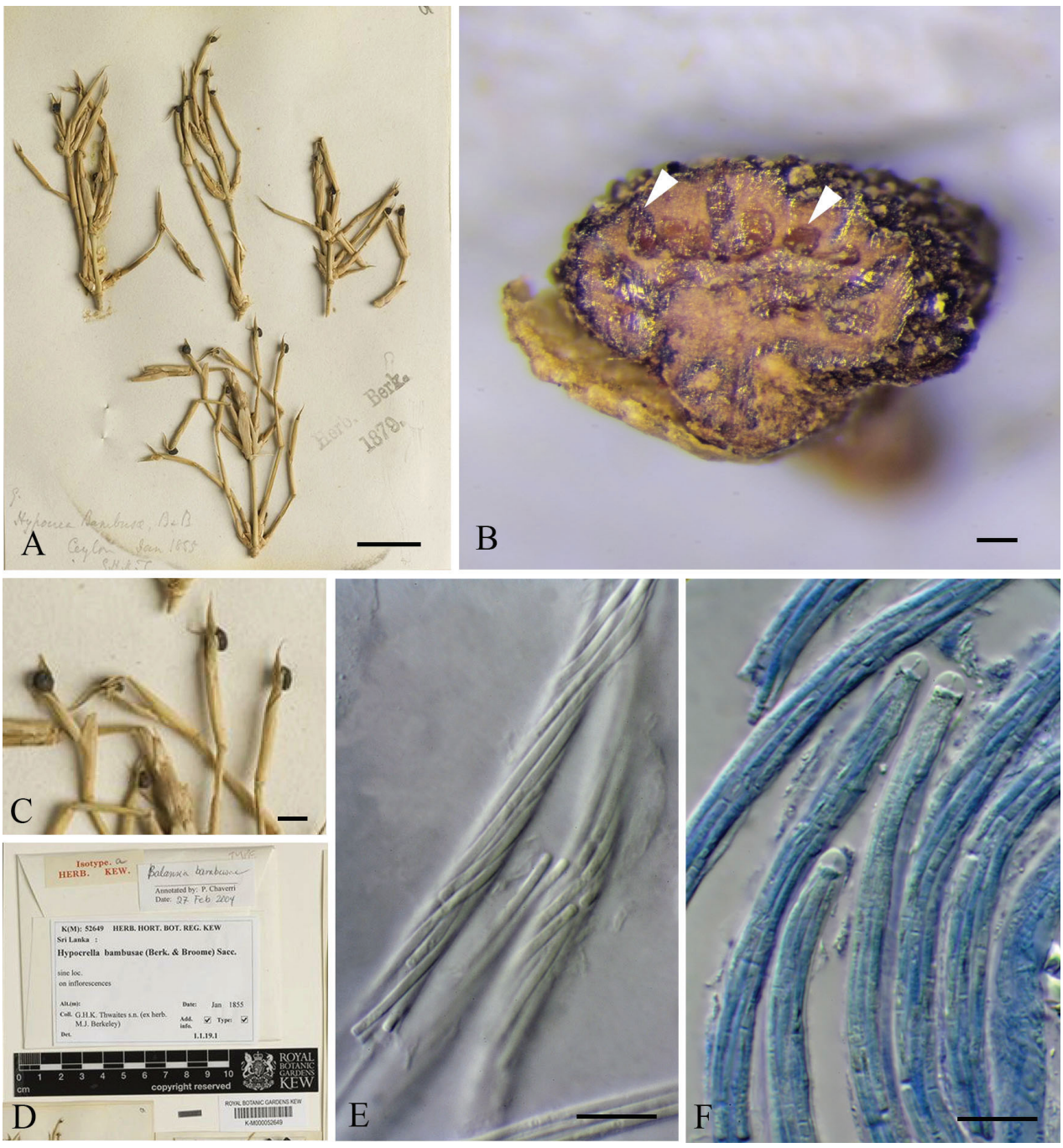

Figure 8. Hypocrella bambusae (K(M)52469, isotype, images are accredited to the Royal Botanic Gardens, Kew) A, C fruiting bodies on inflorescence of bamboo $\mathbf{B}$ vertical section of stromata showing the perithecia locating $\mathbf{D}$ herbarium envelope $\mathbf{E}$ filiform ascospores $\mathbf{F}$ asci with caps (Staining by cotton blue). Scale bars: $5 \mathrm{~mm}(\mathbf{A}), 200 \mu \mathrm{m}(\mathbf{B}), 2 \mathrm{~mm}(\mathbf{C}), 20 \mu \mathrm{m}(\mathbf{E}, \mathbf{F})$.

kotkarn et al. 2008; Liang et al. 2009; Cai et al. 2011; Zhang et al. 2014). Other Shiraia-like endophytes, isolated from the rhizome of Gastrodia, leaves of Huperzia serrata and from Triticum aestivum, phylogenetically cluster within the former group (Fig. 3). However, no hypocrellins were produced from their mycelium (Zhu et al. 2010; Wang et al. 2011, 2016). The bamboo tissue may be providing the needful substances for fungi to produce hypocrellins. The endophytic Shiraia-like taxa (Fig. 3) appear as a distinct genus in Shiraiaceae. The nomination will be made once the type material is available. 
Shiraia bambusicola has been used as a Chinese traditional folk-medicine, in curing rheumatoid arthritis, infantile convulsion and pertussis etc. for more than 400 years, because of its stromatal metabolites (Huang et al. 2001; Shen et al. 2002). Japanese scientists first obtained three perylenequinones from air-dried ascostromata of $S$. bambusicola and named them as hypocrellin A, B and C (Kishi et al. 1991). However, hypocrellin A was originally discovered by Wan and Chen (1981) from a different fungus on bamboo which was called as "Zhuhongjun" in Chinese and was erroneously identified as H. bambusae (Liu 1978). Later the fourth hypocrellin analogue (hypocrellin D) was named by Fang et al. (2006). Therefore, in total, four hypocrellins have so far been named. Hypocrellins are types of biologically active compounds and naturally occurring perylenequinones with photodynamic activity (Wan and Chen 1981; Kishi et al. 1991; Chowdhury et al. 2002; Liang et al. 2009; Liu et al. 2013). These secondary metabolites have gained much attention owing to their light-induced anti-tumour, anti-fungal and anti-viral activities (Wan and Chen 1981; Liang et al. 2009; Li et al. 2000a, b). In clinical trials, hypocrellin shows promising treatment for various skin diseases, such as skin cancer and white lesions of the vulva (Wan and Chen 1981; Li et al. 2000b). In China, a costly medicinal unguent named Bamboo Parasitic Fungus Ointment is made of hypocrellin B (Dai et al. 2018). Interestingly, it was proved that hypocrellin has bactericidal activities which inhibit various bacteria, such as Bacillus subtilis Ehrenberg and Micrococcus luteus Schroeter (Chen et al. 2010). In addition, hypocrellin A has an antiviral activity against human immunodeficiency virus (HIV-1) (Hudson et al. 1994) and is promising as a new-fashioned photoelectric conversion material (Li et al. 2000a).

Hypocrellin has wide application prospects, but it was earlier only found existing in ascostromata of S. bambusicola and "Zhuhongjun" (R. bambusae in this paper) (Wan and Chen 1981; Kishi et al. 1991). For gaining a high yield of Hypocrellin, scientists devoted themselves to looking for strains that can produce hypocrellin through fermentation production (Liang et al. 2009). Numerous endophytes, isolated from bamboo tissue such as culms, leaves, nodes and seeds, were published (Lu et al. 2004; Morakotkarn et al. 2007, 2008; Liang et al. 2009; Cai et al. 2011; Shen et al. 2012, 2014; Zhang et al. 2014), several of which had the potential for hypocrellin production ( $\mathrm{Lu}$ et al. 2004; Morakotkarn et al. 2008; Liang et al. 2009; Zhang et al. 2014; Tong et al. 2017). However, the strains with promising industrial fermentation were identified as Shiraia sp. based on the blast search in GenBank by ITS sequences. More endophytes producing biologically active compounds, such as huperzine, isolated from the plant Huperzia serrata (Thunb. ex Murray) Trev., were also named as Shiraia sp. (Wang et al. 2011, 2016; Zhu et al. 2010). These strains usually have around 80\%-90\% ITS similarity with $S$. bambusicola, which also shows that they are phylogenetically close with members of Shiraiaceae. In this study, these endophytes are placed in Shiraiaceae, based on the phylogenetic analyses (Fig. 3).

According to Deng et al. (2017), polyketide synthase (SbaPKS) is involved in hypocrellin biosynthesis, based on the methods of CRISPR/Cas9 genome editing. It provides evidence for decoding the hypocrellin pathway (Deng et al. 2017). This pathway has the potential for producing high quality hypocrellins. 


\section{Acknowledgements}

This work was supported by the Key Laboratory of Yunnan Province Universities of the Diversity and Ecological Adaptive Evolution for Animals and plants on Yun-Gui Plateau, the National Natural Science Foundation of China (No. NSFC 31760013 , 31950410558, 31260087, 31460561, 31860005, 31460179 and 31860057) and the Scientific Research Foundation of Yunnan Provincial Department of Education (2017ZZX186). Dong-Qin Dai would like to thank Yunnan Province Universities of the Science and Technology Innovation Team for the exploitation and utilisation of endophytes and the Thousand Talents Plan, Youth Project of Yunnan Provinces for support. Chao Liu thanks the Yunnan Local Colleges Applied Basic Research Projects (2017FH001-034). Dong-Qin Dai would like to thank Xiu Gao (Qujing Normal University) for the help with drawing chemical structures of hypocrellins and is grateful to Dr. Joanne E. Taylor for the help of the loaned herbarium.

\section{References}

Amano N (1980) Studies on the Japanese Loculoascomycetes. II. Taxonomic position of the genus Shiraia. Bulletin of the National Science Museum 6: 55-60.

Ariyawansa HA, Kang JC, Alias SA, Chukeatirote E, Hyde KD (2013) Towards a natural classification of Dothideomycetes: The genera Dermatodothella, Dothideopsella, Grandigallia, Hysteropeltella and Gloeodiscus (Dothideomycetes incertae sedis). Phytotaxa 147: 35-47. https://doi.org/10.11646/phytotaxa.147.2.1

Barr ME, Boise JR, Hanlin RT (1987) A spectacular Loculoascomycete from Venezuela. Mycotaxon 29: 195-198.

Berkeley MJ, Broome CE (1875) Enumeration of the fungi of Ceylon. Part II. Botanical Journal of the Linnean Society 14: 29-141. https://doi.org/10.1111/j.1095-8339.1873.tb00301.x

Cai Y, Liao X, Liang X, Ding Y, Sun J, Zhang D (2011) Induction of hypocrellin production by Triton X-100 under submerged fermentation with Shiraia sp. SUPER-H168. New Biotechnology 28: 588-592. https://doi.org/10.1016/j.nbt.2011.02.001

Chem A (2012) Practical HPLC method development. Carbohydrate Polymers 16: 338-338. https://doi.org/10.1016/0144-8617(91)90119-W

Chen H, Chen WQ (2009) The analysis and comparison of bioactive ingredients in Shiraia bambusicola from different regions. Journal of Zhejiang Shuren University 9: 17-19.

Chen YJ, Zhong WW, Yang SY (2010) Study on the Antibacterial Activity of Shiraia bambusicola Henn. Journal of Yunnan University of Nationalities (Natural Sciences Edition) 19: 154-156.

Cheng TF, Jia XM, Ma XH, Lin HP, Zhao YH (2004) Phylogenetic study on Shiraia bambusicola by rDNA sequence analyses. Journal of Basic Microbiology 44: 339-350. https://doi. org/10.1002/jobm.200410434

Chowdhury PK, Das K, Datta A, Liu WZ, Zhang HY, Petrich JW (2002) A comparison of the excited-state processes of nearly symmetrical perylene quinones: hypocrellin $A$ and hypomycin B. Journal of Photochemistry \& Photobiology A: Chemistry 154: 107-116. https://doi.org/10.1016/S1010-6030(02)00309-X 
Dai DQ, Phookamsak R, Wijayawardene NN, Li WJ, Bhat DJ, Mortimer PE, Xu JC, Taylor JE, Hyde KD, Chukeatirote E (2017) Bambusicolous fungi. Fungal Diversity 82: 1-105. https://doi.org/10.1007/s13225-016-0367-8

Dai DQ, Tang LZ, Wang HB (2018) Review of bambusicolous ascomycetes. Bamboo: Current and Future Prospects 2018: 165. https://doi.org/10.5772/intechopen.76463

Deng HX, Gao RJ, Liao, XG, Cai YJ (2017) Genome editing in Shiraia bambusicola using CRISPR-Cas9 system. Journal of Biotechnology 259: 228-234. https://doi.org/10.1016/j. jbiotec.2017.06.1204

Fang LZ, Qing C, Shao HJ, Yang YD, Dong ZJ, Wang F, Zhao W, Yang WQ, Liu JK (2006) Hypocrellin D, a cytotoxic fungal pigment from fruiting bodies of the ascomycete Shiraia bambusicola. Journal of Antibiotics 59: 351-354. https://doi.org/10.1038/ja.2006.49

Hall T (2004) BioEdit. Ibis Therapeutics, Carlsbad. http://www.mbio.ncsu.edu/BioEdit/bioedit.html [18 Mar 2005]

Hennings P (1900) Fungi Japonici. Botanische Jahrbücher für Systematik, Pflanzengeschichte und Pflanzengeographie 28: 259-280.

Hino I (1961) Icones fungorum bambusicolorum japonicorum. The Fuji Bamboo Garden, Kobe.

Huang TK, Ding ZZ, Zhao SX, Yan YQ, Xu GJ, Chen L, Yu CL, Gao XL, Zhang ZD (2001) Xian Dai Ben Cao Gang Mu. China Medical Science Press, Beijing. [In Chinese]

Hudson JB, Zhou J, Chen J, Harris L, Towers GH (1994) Hypocrellin, from Hypocrella bambusae, is phototoxic to human immunodeficiency virus. Photochem Photobiol 60: 253255. https://doi.org/10.1111/j.1751-1097.1994.tb05100.x

Huelsenbeck JP, Ronquist F (2001) MRBAYES: Bayesian inference of phylogenetic trees. Bioinformatics 17: 754-755. https://doi.org/10.1093/bioinformatics/17.8.754

Index Fungorum (2019) Index Fungorum. http://www.indexfungorum.org/names/Names.asp Jayasiri SC, Hyde KD, Ariyawansa HA, Bhat DJ, Buyck B, Cai L, Dai YC, Abd-Elsalam KA, Ertz D, Hidayat I, Jeewon R, Jones EBG, Bahkali AH, Karunarathna SC, Liu JK, Luangsa-ard JJ, Lumbsch HT, Maharachchikumbura SSN, McKenzie EHC, Moncalvo JM, Ghobad-Nejhad M, Nilsson H, Pang KL, Pereira OL, Phillips AJL, Raspé O, Rollins AW, Romero AI, Etayo J, Selçuk F, Stephenson SL, Suetrong S, Taylor JE, Tsui CKM, Vizzini A, Abdel-Wahab MA, Wen TC, Boonmee S, Dai DQ, Daranagama DA, Dissanayake AJ, Ekanayaka AH, Fryar SC, Hongsanan S, Jayawardena RS, Li WJ, Perera RH, Phookamsak R, de Silva NI, Thambugala KM, Tian Q, Wijayawardene NN, Zhao RL, Zhao Q, Kang JC, Promputtha I (2015) The Faces of Fungi database: fungal names linked with morphology, phylogeny and human impacts. Fungal Diversity 74: 3-18. https://doi. org/10.1007/s13225-015-0351-8

Katoh K, Standley DM (2013) MAFFT multiple sequence alignment software version 7: improvements in performance and usability. Molecular Biology and Evolution 30: 772-780. https://doi.org/10.1093/molbev/mst010

Kirk PM, Cannon PF, David JC, Stalpers JA (2001) Ainsworth and Bisby's Dictionary of the Fungi ( $9^{\text {th }}$ edn). CAB International, Wallingford, $655 \mathrm{pp}$.

Kirk PM, Cannon PF, Minter DW, Stalpers JA (2008) Dictionary of the Fungi $\left(10^{\text {th }}\right.$ edn). CABI, Wallingford, 784 pp. 
Kishi T, Tahara S, Taniguchi N, Tsuda M, Tanaka C, Takahashi S (1991) New perylenequinones from Shiraia bambusicola. Planta Medica 57: 376-379. https://doi. org/10.1055/s-2006-960121

Lai GH, Fu LY (2000) Study on main host plants of Shiraia bambusicola. Chinese Wild Plant Resources 1: 8-11. [In Chinese]

Li C, Chen YT, Lin NY, Wang HQ, Liu WZ, Xie JL (2000a) Analysis on the chemical components of a fungus producing perylenequinones photosensitive compounds. Mycosystema 19: $122-127$.

Li C, Wang HQ, Xie JL, Lin NY, Dai WH, Chen YT (2000b) Analysis and comparisons of compounds among three medical fungi of Hypocreaceae. Chinese Traditional and Herbal Drugs 31: 250-251.

Li XM, Gao J, Yue YD, Hou CL (2009) Studies on Systematics, Biology and Bioactive Substance of Shiraia bambusicola. Forest Research 22: 279-284.

Liang XH, Cai YJ, Liao XR, Wu K, Wang L, Zhang DB, Meng Q (2009) Isolation and identification of a new hypocrellin A-producing strain Shiraia sp. SUPER-H168. Microbiological Research 164: 9-17. https://doi.org/10.1016/j.micres.2008.08.004

Liu B (1978) Chinese medicinal fungi ( $\left.2^{\text {nd }} \mathrm{edn}\right)$. Shanxi people's publishing house, Taiyuan. [In Chinese]

Liu YJ, Whelen S, Hall BD (1999) Phylogenetic relationships among ascomycetes: evidence from an RNA polymerse II subunit. Molecular Biology and Evolution 16: 1799-1808. https://doi.org/10.1093/oxfordjournals.molbev.a026092

Liu YX, Hyde KD, Ariyawansa HA, Li WJ, Zhou DQ, Yang YL, Chen YM, Liu ZY (2013) Shiraiaceae, new family of Pleosporales (Dothideomycetes, Ascomycota). Phytotaxa 103: 51-60. https://doi.org/10.11646/phytotaxa.103.1.4

Liu JK, Hyde KD, Jeewon R, Phillips AL, Maharachchikumbura SSN, Ryberg M, Liu ZY, Zhao Q (2017) Ranking higher taxa using divergence times: a case study in Dothideomycetes. Fungal Diversity 84:75-99. https://doi.org/10.1007/s13225-017-0385-1

Lu MF, Huang YB, Zhang HY, Wang HN, Zhang YJ (2004) Cloning and sequencing of the ITS in rDNA Gene of a Fungus Producing Perylenequinones Deriveration. Journal of Sichuan Agricultural University 22: 138-141. https://doi.org/10.1300/J064v24n01_09

Lumbsch HT, Huhndorf SM (2010) Myconet Volume 14. Part one. Outline of Ascomycota-2009. Part Two. Notes on Ascomycete Systematics. Nos. 4751-5113. Fieldiana Life and Earth Sciences 1: 1-64. https://doi.org/10.3158/1557.1

Maharachchikumbura SS, Hyde KD, Jones EBG, McKenzie EHC, Huang SK, Abdel-Wahab MA, Daranagama DA, Dayarathne M, D’souza MJ, Goonasekara ID, Hongsanan S, Jayawardena RS, Kirk PM, Konta S, Liu JK, Liu ZY, Norphanphoun C, Pang KL, Perera RH, Senanayake IC, Shang Q, Shenoy BD, Xiao YP, Bahkali AH, Kang JC, Somrothipol S, Suetrong S, Wen TC, Xu JC (2015) Towards a natural classification and backbone tree for Sordariomycetes. Fungal Diversity 72: 199-301. https://doi.org/10.1007/s13225015-0331-z

Morakotkarn D, Kawasaki H, Seki T (2007) Molecular diversity of bamboo-associated fungi isolated from Japan. FEMS Microbiology Letters 266: 10-19. https://doi.org/10.1111/ j.1574-6968.2006.00489.x 
Morakotkarn D, Kawasaki H, Tanaka K, Okane I, Seki T (2008) Taxonomic characterization of Shiraia-like fungi isolated from bamboos in Japan. Mycoscience 49: 258-265. https:// doi.org/10.1007/S10267-008-0419-3

Nylander JAA (2004) MrModeltest 2.0. Program distributed by the author. Evolutionary Biology Centre, Uppsala University

Page RDM (1996) TreeView: an application to display phylogenetic trees on personal computers. Computer Applications in the Biosciences 12: 357-358. https://doi.org/10.1093/ bioinformatics/12.4.357

Phillips AJL, Alves A, Abdollahzadeh J, Slippers B, Wingfield MJ, Groenewald JZ, Crous PW (2013) The Botryosphaeriaceae: genera and species known from culture. Studies in Mycology 76: 51-167. https://doi.org/10.3114/sim0021

Phookamsak R, Liu JK, McKenzie EHC, Manamgoda DS, Ariyawansa H, Thambugala KM, Dai DQ, Camporesi E, Chukeatirote E, Wijayawardene NN, Bahkali AH, Mortimer PE, Xu JC, Hyde KD (2014) Revision of Phaeosphaeriaceae. Fungal Diversity 68: 159-238. https://doi.org/10.1007/s13225-014-0308-3

Rannala B, Yang Z (1996) Probability distribution of molecular evolutionary trees: a new method of phylogenetic inference. Journal of molecular evolution 43: 304-311. https:// doi.org/10.1007/BF02338839

Rehner S (2001) Primers for elongation factor 1- $\alpha$ (EF1- $\alpha$ ). http://ocid.NACSE.ORG/research/deephyphae/EF1primer.pdf

Ronquist F, Huelsenbeck JP (2003) MrBayes 3: Bayesian phylogenetic inference under mixed models. Bioinformatics 19: 1572-1574. https://doi.org/10.1093/bioinformatics/btg180

Saccardo PA (1878) Enumeratio pyrenomycetum Hpocreaceorum hucusque cognitorum systemate carpologico dispositorum. Michelia 1: 277-325.

Saccardo PA (1902) Sylloge Fungorum. Omnium hucosque cognitorum. Supplementum universale XVI: 421

Shen YX, Rong XG, Gao ZH (2002) Studies on the chemical constituents of Shiraia bambusicola. China Journal of Chinese Materia Medica 27: 674-677.

Shen X, Zheng D, Gao J, Hou CL (2012) Isolation and evaluation of endophytic fungi with antimicrobial ability from Phyllostachys edulis. Bangladesh Journal of Pharmacology 7: 249-257. https://doi.org/10.3329/bjp.v7i4.12068

Shen XY, Cheng YL, Cai CJ, Fan L, Gao J, Hou CL (2014) Diversity and Antimicrobial Activity of Culturable Endophytic Fungi Isolated from Moso Bamboo Seeds. PloS one 9: e95838. https://doi.org/10.1371/journal.pone.0095838

Silvestro D, Michalak I (2011) raxmlGUI: a graphical front-end for RAxML. Organisms Diversity \& Evolution 12: 335-337. https://doi.org/10.1093/bioinformatics/btg180

Stadler M, Wollweber H, Mühlbauer A, Henkel T, Asakawa Y, Hashimoto T, Rogers JD, Ju YM, Wetzstein HG, Tichy HV (2001) Secondary metabolite profiles, genetic fingerprints and taxonomy of Daldinia and allies. Mycotaxon 77: 379-429.

Stamatakis A (2006) RAxML-VI-HPC: maximum likelihood-based phylogenetic analyses with thousands of taxa and mixed models. Bioinformatics 22: 2688-2690. https://doi. org/10.1093/bioinformatics/btl446

Swofford DL (2002) PAUP: phylogenetic analysis using parsimony, version 4.0 b10. Sinauer Associates, Sunderland. https://doi.org/10.1002/0471650129.dob0522 
Tamura K, Stecher G, Peterson D, Filipski A, Kumar S (2013) MEGA6: molecular evolutionary genetics analysis version 6.0. Molecular Biology and Evolution 30: 2725-2729. https:// doi.org/10.1093/molbev/mst197

Tong ZW, Mao L, Liang H, Zhang Z, Wang Y, Yan R, Zhu D (2017) Simultaneous Determination of Six Perylenequinones in Shiraiaia sp. Slf14 by HPLC. Journal of Liquid Chromatography \& Related Technologies 40: 536-540. https://doi.org/10.1080/10826076.20 17.1331172

Vilgalys R, Hester M (1990) Rapid genetic identification and mapping of enzymatically amplified ribosomal DNA from several Cryptococcus species. Journal of Bacteriology 172: 4238-4246. https://doi.org/10.1128/jb.172.8.4238-4246.1990

Wan XY, Chen YT (1981) Hypocrellin A-A new drug for photochemotherapy. Chinese Science Bulletin 26: 1040-1042.

Wang Y, Zeng QG, Zhang ZB, Yan RM, Wang LY, Zhu D (2011) Isolation and characterization of endophytic huperzine A-producing fungi from Huperzia serrata. Journal of Industrial Microbiology \& Biotechnology 38: 1267-1278. https://doi.org/10.1007/s10295010-0905-4

Wang Y, Zheng L, Li XX, Yan RM, Zhang ZB, Yang HL, Zhu D (2016) Isolation, diversity and acetylcholinesterase inhibitory activity of the culturable endophytic fungi harboured in Huperzia serrata from Jinggang Mountain, China. World Journal of Microbiology \& Biotechnology 32: 1-23. https://doi.org/10.1007/s11274-015-1966-3

White TJ, Bruns T, Lee S, Taylor J (1990) Amplification and direct sequencing of fungal ribosomal RNA genes for phylogenetics. In: Innis MA, Gelfand DH, Sninsky JJ, White TJ (Eds) PCR protocols: a guide to methods and applications, Academic, San Diego, 315322. https://doi.org/10.1016/B978-0-12-372180-8.50042-1

Wijayawardene NN, Crous PW, Kirk PM, Hawksworth DL, Boonmee S, Braun U, Chomnunti P, Dai DQ, D'souza MJ, Diederich P, Dissanayake A, Doilom M, Hongsanan S, Jones EBG, Groenewald JZ, Jayawardena R, Lawrey JD, Liu JK, Lücking R, Madrid H, Manamgoda DS, Muggia L, Nelsen MP, Phookamsak R, Suetrong S, Tanaka K, Thambugala KM, Wikee S, Zhang Y, Aptroot A, Ariyawansa HA, Bahkali AH, Bhat JD, Gueidan C, De Hoog GS, Knudsen K, McKenzie EHC, Miller AN, Mortimer PE, Wanasinghe DN, Phillips AJL, Raja HA, Slippers B, Shivas RS, Taylor JE, Wang Y, Woudenberg JHC, Piątek M, Cai L, Jaklitsch WM, Hyde KD (2014) Naming and outline of Dothideomycetes. (2014) including proposals for the protection or suppression of generic names. Fungal Diversity 69: 1-55. https://doi.org/10.1007/s13225-014-0309-2

Wijayawardene NN, Papizadeh M, Phillips AJL, Wanasinghe DN, Bhat DJ, Weerahewa HLD, Shenoy BD, Wang Y, Huang YQ (2017) Mycosphere Essays 19: Recent advances and future challenges in taxonomy of coelomycetous fungi. Mycosphere 8: 934-950. https://doi. org/10.5943/mycosphere/8/7/9

Wijayawardene NN, Hyde KD, Lumbsch HT, Liu JK, Maharachchikumbura SSN, Ekanayaka AH, Tian Q, Phookamsak R (2018) Outline of Ascomycota: 2017. Fungal Diversity 88: 167-263. https://doi.org/10.1007/s13225-018-0394-8

Zhang M, Pang W, Wang J (2014) Effect of oxidative stress on hypocrellin A yield in submerged cultures of endophytic Shiraia sp. A8. Planta Med 80: P1N2. https://doi. org/10.1055/s-0034-1394593 
Zhaxybayeva O, Gogarten JP (2002) Bootstrap, Bayesian probability and maximum likelihood mapping: exploring new tools for comparative genome analyses. BMC Genomics 3: 4. https://doi.org/10.1186/1471-2164-3-4

Zhao D, Liang ZQ (2005) Reviews of Studies on Isolation and Culture of Shiraia bambusicola Henn. Journal of Fungal Research 3: 53-57.

Zhu D, Wang JX, Zeng QG, Zhang ZB, Yan RM (2010) A novel endophytic huperzine Aproducing fungus, Shiraia sp. Slf14, isolated from Huperzia serrata. Journal of Applied Microbiology 109: 1469-1478. https://doi.org/10.1111/j.1365-2672.2010.04777.x 